\title{
A RESEARCH AGENDA ON CZECH ATTITUDINAL PERSPECTIVES IN AN ERA OF DIGITAL TRANSFORMATION
}

\author{
Richard Brunet-Thornton \\ University of Economics, Prague, Czech Republic \\ Tobias Cramer \\ University of Economics, Prague, Czech Republic \\ Petr Jirsák \\ University of Economics, Prague, Czech Republic
}

\begin{abstract}
This discussion centres on the growing impact of the transformation to digitalisation in various industry sectors. Enterprises seek to engage individuals who possess an appropriate profile to fulfil vacancies or new positions to assist in the transformation endeavour. Traditional job descriptions are replaced by the need for agile technical skills, project management competencies, and critical thinking. Challenges increase proportionally to the local employment rate. To evaluate such an impact, a project has been established to determine the reaction of employers once confronted with the lack of same-culture candidates. This manuscript represents the first phase of the project wherein the status quo is documented through an analysis of the extant literature. The findings of this exercise then serve as a benchmark from which survey results are monitored. Although the literature review does not dispel all Czech stereotypes, it does provide a more realistic image of Czech cultural traits and characteristics.
\end{abstract}

Keywords: Czech Republic, Research project, Culture and diversity, Stereotypes, Workplace and management, HRM.

DOI: http://dx.doi.org/10.15549/jeecar.v6i1.277

\section{INTRODUCTION}

Unlike some cultures prone to edited selfcriticism that highlights the more positive aspects of a social dilemma or at the extreme, societies in which any critique is viewed as injurious to the national psyche, Czechs may be perceived as unnecessarily brutal in their introspection. Captured from the accounts of
Czech sociologists, expatriates, and journalists during the early transition period of the 1990s, Czechs represented a homogeneous society prone to xenophobia, hedonism, corruption, rampant atheism, and provincialism (Holý, 1996, Kuraš, 1998, Lord, 2004, Pehe, 1995, 1996, and Urban, 1995, 1996). Furthermore, based on the Hofstede cultural dimensions, the Czech nation suffers from centralised decision 
structures (Hofstede, 2001:107); the fear of failure (ibid: 169); the lack of group identity (ibid: 244); live in order to work (ibid: 318); general resistance, cynicism and pessimism (ibid: 383). Hofstede (2001) does acknowledge that no formal study was conducted in the Czech Republic and that the ascribed cultural dimensions were developed heuristically Apologetics, both Czech and external, more recently have become more appreciative in their evaluations, however, since the 2004 European Union adhesion, little attention has been awarded to the Czech Republic from the 'out of country' academic populace.

In many prominent sectors such as foreign direct investment, international negotiations, and above all, international business instruction, training and consultancy, reliance remains heavily on cultural models developed during the Cold War with little pertinence to the globalised environment. The latter scenario is further aggravated by the increased emphasis on what is commonly termed as the rise of the Digital Age, one that promotes transference and transformation to the varied aspects of digitalisation. Termed as Digital Transformation in the European Union (European Commission, 2018) or in the Czech Republic, Průmysl 4.0 (ibid.), the Czech equivalent to the original nomenclature coined by the German government in 2011 as Industrie 4,0, national economies seek to increase productivity and better the human condition.

It is in this light that an internal project entitled, Workplace and Management Challenges in the Digital Era - Investigating Czech Attitudinal Perspectives on Organisational Culture, Gender Equality, and Diversity, sanctioned by the Faculty of Business Administration of the University of Economics, Prague, investigates the contemporary Czech sociocultural and economic perceptions relative to the era of digital transformation. Specifically, the initial phase comprises a detailled review of the literature pertinent to the country in the relative topics of organisational culture that includes HRM, gender equality and diversity.

The resulting artefact of this initial phase gauges the contemporary state of Czech cultural and organisational dimensions albeit compiled from secondary sources. The need for research stems from the lack of authoritative material that encompass updates to existing Czech cultural traits and perspectives that today often comprise outdated typecasts. The subsequent research questions deal directly with these contemporary reviews on the elements identified previously: culture, diversity, gender equality, Human Resource Management, and finally, organisational behaviour and culture.

Ultimately, the authors' aspiration centres on an application of a modified Hay Addressing Framework (2008, 2012) within a Czech employer context. The Czech Republic enjoys the lowest unemployment rate in the European Union (Eurostat, 2018). This in turn, creates national labour shortages not only in traditional industries but in those seeking competitive advantages and financial growth subsequent to digital transformation. Within this milieu, the research project deploys the current literature review as a benchmark from which future findings are analysed. The latter are derived from focus groups that comprise employers and HRM specialists coupled with self-administered questionnaires addressed to the corporate employees, the candidates' future co-workers.

As illustration of a typical example of the Hays Addressing Framework (HAF), the following scenario is proposed. A Czech employer seeks an IT specialist from two potential employees. One candidate is a single heterosexual white male of Eastern European extraction, who holds a recent postgraduate degree in Computer Science but possesses little 'hands on' practice versus a female of colour, French national, civil partnership with a female spouse and two children, holds a bachelor's degree in Computer Science and 10-years' experience with the IT international branch of French telecommunications carrier. This example, as mentioned above, is solely a conceivable application of the HAF. However, it does serve to identify the environment from which Czech attitudinal perspectives are measured and compared with the literature review as benchmark.

\section{DISCUSSION FORMAT}

Suitable to a review of this nature, the challenges of contemporary national cultural models expose the laxity regarding Czech 
characterisation. Following which, this examination addresses diversity. Diversity, as defined by Diller (2019), not only considers sexual orientation and race, albeit important elements today, but also facets of ageism, and physical and mental impairments. Increasingly, gender in recent years gained significant interest, rightfully so, given contemporaneous attitudes in the Western world. Gender equality thus follows as an important factor in globalised enterprises and multinational cultures. Inclusivity remains not a buzzword but as a criterion of corporate leadership, organisational culture and behaviour that in turn, stimulates the respective HRM.

\section{CZECH CULTURAL VALUES}

\section{Defining Czech Values}

"Hofstede, it can be said, tamed the beast, he divided it, counted it, tabled it, and graphed it. 'Culture' was reduced to 'values', which were reduced to a limited set of questions on an IBM questionnaire. 'National society' was reduced to 'middle class' rather than 'working class' which was reduced to IBM personnel for marketing and service divisions. Answers were quantified, computerised, 'statisticalised'. Things cultural could be said in 'scientific' language" (Ailon, 2008: 886).

Many intercultural researchers dismiss Hofstede and other similar contributors to the discussion; however, it is crucial to admit that without the Hofstedean dimensions, this analysis would not be warranted. Dissatisfaction with the contemporary cultural constructs in an era of Western feminism, extremist religious movements, and populist governments, promote a high degree of cultural adaptation to cope with these extraordinary societal conditions. Culture can no longer be viewed as static that changes in snail-like movements over generations. Leung at al. (2005) propose "a dynamic view of culture" in that culture "is represented by cognitive structures and processes that are sensitive to environmental influences" (ibid., 366). Despite the continuous search for practical models, Taras et al. (2012:33) warn that the [Hofstede] model is here to stay at least until 2050 although some dimensions "becoming fully disconnected between 2020 and 2030".
Lenski (1970:44) proposes that "values are the moral beliefs to which members of a group subscribe". Typically, values comprise what is permissible within the society, what actions are deviate, and those that are forbidden. Ideal values alter individuals and therefore, cultures form ego-centric beings to member associated ones. Luthans and Doh (2009:11) provide a simple but practical perspective in that values are "basic convictions that people have regarding what is right and wrong, good and bad, important and unimportant". The discussion shifts as to whether values exist that subsequently influence culture or if culture contains inherent values. It may be considered somewhat of a situation in which it is impossible to say which of two things existed first and which in turn, caused the other scenario.

Mansfeldová (2003) analyses specific Czech attitudes towards democracy and associated values during the period 1990 - 2001. Using various sources such as the European Values Study, New Democracies Barometer and others, she identifies some of the central differences between the earlier views of 1990 with those of 2001. The most significant of these being the general lack of experience of the populace with democratic models and institutions. Findings indicate that over seventy percent held a preference to the democratic model. (ibid). In this context, the model comprises liberties, social equality, gender equality, and other traditional Western values. Not surprisingly, the Czechs viewed with a high level of satisfaction the overall development in the political arena in that it had changed substantially. When queried as to the level of satisfaction of politics, "worse than expected' increased from 32,8 in 1990 to 51,3 in 2001.

Czechs were confronted with drastic change. The transition required more than words and positive sentiment. Echoed by the CATO Institute, "a popular refrain in the early 1990s said that "there is no precedent for moving from socialism to capitalism'” (Havrylyshn, 2007:2). The report reviews the pace of reforms exercised by the transitory countries following the events of 1989-92. It regards reforms not only from a financial but a social aspect and divides these political entities into 'big-bangers' 
and 'gradualists. Illner (1994) does address the issue "of focusing on actors and more specifically, on the institutional actors the question of the international environment of transformation (ibid., 22). In doing so, he analyses the international dimension of transition specific to the Czech Republic during its adoption of Western and European standards. Illner foresaw the role of Germany of high importance to the incorporation of the Czech business and management members into Western European frameworks. Illner highlights one issue being the cultural and historical relationship between both countries specifically, in the recent past. Although current statistics demonstrate a rise of a positive generational-based opinion, his overall suggestion is not to centre on issues relative to the Sudeten. Likewise, guidance and recommendations are made to address each of the Visegrád Four nations: Slovakia: peaceful separation, little probability of conflict; Poland: territorial dispute, dormant popular prejudices, and Hungary: no specific mention (ibid., 25). One positive reflection is that all four countries indicated the wish to join the European Union and NATO. For the Czechs, adhesion to the EU reaffirms the country's return to Western values, with NATO membership guaranteeing the nation's security. Given that the Illner manuscript was published in 1994 during a period still early in the transition, upon reflection, two value progressions are of significance today. He refers to the period between the formation of the First Republic and the Nazi occupation in 1938 and revisits the "democratic models as well as standards of both political behaviour and institutions" (ibid., 38) which remain in the Czech conscientiousness thus, enabling the survival and fruition of democracy. In reference to values prominent to the Czech spirit, 'sobriety and scepticism' (ibid, 34). Both values resist against political extremism. However, Czech scepticism "has been frequently associated with narrowmindedness, provincialism, and the ability both to appreciate bold projects and to be motivated by universal values" (ibid.).

Another examination investigates the conditions of the "countries that shook off Soviet-style tyrannies a generation ago" (Shleifer and Treisman, 2014:1). The theme of their discussion illustrates the progress made since 1989 despite the often-negative media that degrades the many success stories. Topics such as living, and health standards, politics and corruption are covered. However, imperative to mention that the Europe presented is one of a pre-Brexit, mass migration, Russia-Ukraine conflict, and the upsurge of conservative rightwing governments. As to normalcy when compared with more long-standing democratic peers, they describe the Czech Republic as "radical reformers' having achieved an upgrade of over forty points during the first three years of transition" (ibid., 10). The points refer to the matrix used by the authors to measure speed of reform. The points represent indicators developed by the European Bank for Reconstruction and Development, EBRD.

Smith and Matějů (2012) propose that Czech values become progressively stratified by objective social status. Based on views of the fallout from the collapse of the former regime, much of the research foretold that the transition would be accompanied with a move towards rewards based on merit-based principles. This signifies that rewards, financial and others, are related to productivity and efficiency. An individual's merit replaces entitlement. Egalitarian principles espoused by the Communist party were often difficult to eliminate "in the early 1990s [is that] the emerging political and economic system in post-Communist countries lacked societal legitimacy" (ibid., 425). Due to continued corruption scandals, latent market improvements, citizens sought a sense of continuity, thus maintaining a reliance on egalitarian values rather than the meritocratic. One of the elements analysed in their study covered the historical change in the crystallisation of meritocratic and egalitarian values in four western countries, West Germany, Great Britain, Netherlands, USA and seven post-Communist countries: Bulgaria, Czech Republic, East Germany, Hungary, Poland, Russia, and Slovenia.

The hypotheses proposed by Smith and Matěju (2012) are that the association between meritocracy and egalitarianism in the Czech Republic approach are comparable to those in the former West, "our overall analytical 
perspective is that the crystallisation of distributive justice norms... have reached typical "western" levels over time; i.e., after its transition to a market economy reached completion" (ibid., 429). They provide the following definition, "value crystallisation refers not only to the degree of opposition of the two main justice ideologies, but their ability to organise the diverse and often complex set of justice beliefs into coherent belief systems" (ibid., 431). The Czech results demonstrated a progressive development of value crystallisation to obtain the same degree as that of West Germany by 2009 . Czech values are comparable, if not the same as those exhibited in the West.

Piurko, Schwartz and Davidov (2011) in their review of basic personal values and their significance to left-right wing political alignments, studied twenty countries. They contribute further to this discussion in their analysis of basic personal values. For the purpose of their study, they divided the countries into three distinct categories: liberal, traditional, and Post-Communist. Out of the twenty countries that form the basis of the study, four comprise the Post-Communist, Czech Republic, Hungary, Slovenia, and Poland. The study results are summarised as follows, "the Czech Republic exhibited a pattern unique among the 20 countries" (ibid., 2011:15). There exists an additional demarcation in the study wherein left is associated with Western liberalism whereas, right denotes a more conservative tradition. However, the authors do note that in the Post-Communist, the distinction between the two values may be more fluid due to their common Communist experience. Study results demonstrate that the Czech Republic includes the values of achievement, hedonism, security, self-direction, stimulation, and conformity/ tradition (ibid., 2011;16).

Piurko, et al. (2011) categorise the Czech Republic as a post-Communist society. Citing Markowski (1997), the rapid movement towards the West created populist right-wing nationalism, and religiosity. From their study, the Czech Republic ranks slightly over the midrange $(5,45)$ signifying there is a weaker tendency to a right-wing political orientation. As with many studies of this nature, Czech results were unique. Further scrutiny revealed that Czech respondents possess a politically right orientation to openness to change but left to security and conformity issues, In the domain of value achievements, Czech value attributes include hedonism, security, self-direction, stimulation, and the unified conformity / tradition values. The findings specific to the Czech Republic within the resulting value identifiers contribute to a comprehensive listing of characteristics. Self-direction is synonymous with originality, independence in decisionmaking, and innovation. Security is associated not only with personal well-being but includes government awareness of internal and external threats and the ability to provide the suitable response. Enjoying oneself is directly associated with hedonism. To seek new opportunities and adventures constitutes stimulation. Lastly, a dichotomy between tradition and hedonism wherein the former indicates modesty. Conformity always signifies proper behaviour. The results demonstrate that the Czech Republic include the values of achievement, hedonism, security, self-direction, stimulation, and conformity/tradition (ibid).

Danis and colleagues (2011) evaluate values, specifically Czech managers, professionals, and business students, as to generational differences. The authors selected the Czech Republic basically due to its inherent Western qualities, its rapid withdrawal from the past years of totalitarianism, and its previous experience with democratic institutions. The hypotheses use among others, the value definitions proposed by Ralston et al (1993), "values determine the bounds of ethical behaviours, define success or failure, and affect how managers are influenced by external pressures"; Inglehart (1997), "value systems can change over time, particularly when situations arise that challenge established norms or cause a re-examination of value structures", and the Schwartz Value Survey (Schwartz, 1992) and its ten universal values. To some degree, the results are not surprising. The study determines that a generational divide exists between pre- and post-transitional Czechs in their respective value sets. The contributing factor reflects the educational and social upbringing between both groups (ibid., 300). Of interest, the authors conclude, "it is possible that societal value systems may change within a generation due to 
sudden, extreme changes in life circumstances, such as those that have taken place in postCommunist countries like the Czech Republic" (ibid.: 301). This statement further questions the validity of Hofstede's (2010) premise that cultures remain static over time and that change is slow and incremental.

On the more fundamental value of freedom and democracy, significant challenges have besought the young republic from the beginning with the division of the CzechoSlovak state into two separate political entities. Unlike many other post-Communist entities, due to its relatively homogeneous cultural composition, the Czech state did not suffer from an internal crisis. This played in the Czech favour throughout the process of nation building and the establishment of democratic institutions (Pridham, 2009:2). The government's concentration on business and finances rather than the government itself promoted a positive image to the world at the time. It was later downgraded by the disastrous 'EU presidency' and the 'Eurosceptic antics of the state president' (ibid., 3). "The Czech Republic was the darling of the West, a self-perpetuating status thanks to the shared impressions of Western policy makers and the (most) favourable crossreferenced reports of international organisations" (Vachudová, 2011:330).

Unlike its neighbours, Czechs benefited from twenty years of democracy and liberalism prior to the outbreak of the second world war. During the period subsequent to 1948 , the Czech value system remained dormant to be revitalised during the brief period of 1968 and finally to be restored in 1989. During the short reprieve of the Prague Spring, and the period of normalisation that followed, "from now on the apparent humanist and democratic legacy of Czech history was not invoked in order to legitimise some kind of socialist reform project, but in a bid to reconsider Czech historical experiences from the perspective of universal as well as domestic genealogy of human rights and civil freedoms" (Kopeček, 2009).

\section{Post-Communist Syndrome}

There are still remnants of life within the Communist sphere that continue to haunt the Czech sense of value. Varying degrees of xenophobia and an increasingly inclusiveness associated with Czechness remain prevalent. Rabušic (2001:100) mentions change in value orientations from one generation to the next as an "unavoidable effect of the Czech 'Velvet Revolution' and of the subsequent transformation process". Recognising that those individuals born post 1989 have enjoyed privileges surpassing all expectations of their parents, are better educated and well-travelled will benefit Czech society with values learnt and experiences gained outside the country.

In the European Union and the Western world today, issues related to xenophobia, cultural, sexual, and gender diversity, multiculturalism, and social inequality are at the forefront of postmodern social values. One only needs to verify official and reputable media outlets to understand the intensity of these issues that oftentimes compromise values through circumstances, stereotyping, and other bias. The origins of these issues are qualified as fragments of the former regime.

In a poll conducted in March 2011, 55\% of Czechs agreed that employing aliens was an acceptable practice (Hokovský and Janda, 2013:78). Additionally, statistics demonstrate that an increase from 2,0 to $4,5 \%$ over a nineyear span starting in 2000. However, this publication was released prior to the European migrant crisis. During the period prior, Ukrainians and Vietnamese constituted the bulk of migrants to the country. Very few in either group seek citizenship. As for the Roma, actual numbers are difficult to assess; estimates vary between 200 to four hundred thousand. The Rom are not considered as being immigrants as the majority are permanent residents.

Issues of immigration up until 2015 were often ignored and seldom discussed politically. Recognising that the Czech Republic is relatively homogenous when compared with other European cultures there was little need to raise the issue. Tomáš Vandas warned the Czech nation in 2011 against immigration and its consequences (Ibid., 94). Other members of his political party openly criticised the Vietnamese for their perceived organised crime. Defining minority groups outside of the Czech majority falls into minorities who possess citizenship and foreigners. Blažejonská (2013) raises an 
interesting connotation, "in Czechia, the title 'foreign national' is being used much more frequently than 'immigrant' that can mean an effort to keep these individuals completely outside symbolically---they are not coming to our group, they are not newly incoming immigrants, they are foreign and will stay foreign" (ibid., 261). Czechs recognise the largest ethnic minority as Slovaks, and do not form part of the integration process due to their past association within the former CzechoSlovak state. However, the Rom minority is largely the group subjected to integration due to their natural exclusion from the Czech mainstream.

One of the difficulties within the national policy is that up to 1993, Czechs emigrated and few, except those from other Soviet Bloc countries immigrated. Czechs, therefore, have been deprived of the experience from a practical sense and politically, adopted EU policies as part of the acquis communautaire. Therefore, there lacks a unique Czech model. After the Velvet Revolution, with the return of former citizens and family members from the diaspora, regulations were lax. During the return to Europe phase, the supranational body-imposed standards and policies.

Multiculturalism is not a term used in the Czech Republic. It denotes the opposite to assimilation. When either term is used, images of Canada being a cultural mosaic versus the American 'melting pot' come to mind. In an interview conducted by Marek Čaněk and Jan Grill (2000) with Pavel Barša, a well-known Czech political scientist. Barša shares with the interviewers that the political right often uses the term in a 'pejorative' sense (ibid., 16). With the events of 2001, emphasis has been allocated to integration rather than to cultural accommodation.

Irritating statements made by then Prime Minister Klaus suggesting that the EU should join the Czech Republic rather than the opposite, his government still managed to safeguard the positive image abroad. One area of contention however, remained the treatment of the Roma minority (Vachudová, 2001:326). At the time of writing her piece on racial and ethnic approaches, Stanlick (2007) states that the Czech Republic, although having compiled a constitution in 1992 did not have either legislation or a policy to address minorities. Once a member of the EU, the Czech Republic was obliged to adopt anti-discrimination laws and policies. However, despite the legislation, little has been done to mitigate the circumstances of this minority. Blažejovská (2013) states that the bulk of the Rom currently in the Czech Republic are 'stateless' not having benefitted from the timeframe allotted to select citizenship after the dissolution of CzechoSlovakia. She remarks that in 2010, the World Bank suggests that the country is deprived of the benefits of an additional nine billion CZK annually due to the high degree of Rom unemployment.

Roma bias forms the centrepiece of the Richard (2014) discussion. From interviews with both Czechs and Roma, he collected data as a visiting professor in Olomouc in 2002. He identifies Czech society as "highly segregated" (ibid., 15). As a primary self-definition Czechs, have defined themselves as a "narrow, homogeneous, enclosed community...strengthened during decades of communism when the regime exploited Czech nationalism to ferment xenophobia against those who came from the outside world" (ibid., 18). To support his research, he claims that the animosity against the Rom dates as early as the nineteenth century during the era of Empire but was strengthened by the Communist regime. "Czech society defined itself defensively against the mostly Germanic world as a narrow, homogenous, enclosed community, an attitude that strengthened during decades of communism, when the regime exploited Czech nationalism to foment xenophobia against those who came from the outside world" (2014:16). Many national circles believe that the Rom issue has been imported. During the second world war, the majority of Roma were annihilated in the Nazi camps. Following the conflict, Rom migrated to Czechoslovakia from Hungary and Romania settling in the eastern areas of Slovakia. During the Communist stage, the Rom were further displaced by the government from Slovakia to Bohemia and Moravia to live in panelák. "In state social policy, the Roma were dealt with as a socially backward group of the population, and the state's remedies were confined to various forms of social support" (Vrabcová, Vacek and Lašek, 2008:11) and in 
doing so, created a relationship of state dependence. Dunbar and Simonová (2003) reflect upon two previous studies conducted during the Czech transition period to $\mathrm{EU}$ adhesion.

Nedomová and Kostelecký (1997) suggest that with the dissolution of CzechoSlovakia, this rendered Czech culture and society homogenously ethnic. In doing so, Czech identity excludes Jews, Roma, and Orientals. Czech citizenship is not awarded but inherited through direct affiliation in this distinct group.

The Dunbar and Simonová study tested both the Czech and American cultures as to their sentiments on Jews and Roma for the Czech version and Jews and Blacks for the American. Not only is the basis of this study of interest, the comparison of the two minority groups in both countries but equally, that is, the nature of the demographics of both populations engaged in the study. "It appears that men in the Czech Republic (and perhaps elsewhere in Eastern Europe) more readily embrace outgroup bias as a normative social attitude and ascribe to cynicism and authoritarianism as a solution to intergroup relations" (Dunbar and Simlonová, 2003:13). Cultural mix in the Czech Republic is remarkedly lacking wherein the US, diverse. The authors comment that comparable to the Rom experience of the second world war, a native Czech Jewish population is equally lacking.

Differences between the Czech and the US respondents comprise gender (Czech) and economics (American). Czech males exhibited a 'predisposed outgroup hostility'. Variances in anti-Semitism were remarked given that $20 \%$ of the American respondents were Jewish. The authors also comment that daily contact between Jews and members of other faiths added to the differences. However, findings demonstrate comparable attitudes. Given the absence of a significant Jewish population in the Czech Republic the authors declare that the claim "one can have anti-Semitism without the presence of Jews" (Marta Alpert, personal communication, January 14,2000 , cited in ibid., 520 ) is valid.

\section{The Idea or Vision of Values}

The move from the Communist set of values or lack thereof, to one that, for the most part is
Western-centric, Europeanised, and global within one generation not only disproves or at least highly questions the Hofstedean principle of static culture. The transition from state sponsored socialism to a democratic and market-based entity may be compared to the transition from industrial to post-industrial values. Using this analogy, the rise of postindustrial values brings declining respect for authority and growing emphasis on participation and self-expression" (Inglehart and Welzel, 2005:43). For the Czechs, postindustrial or post-adhesion values may not be sufficient. Associated with the postmodern society with postmaterialist values emphasises 'self-expression and quality of life' (Ibid., 97). As with any change and, with values and value adjustment, the initial step must be with the identification of the values aspirations. Recognising that this aspiration whether consciously or subconsciously as an effort, the culture may then identify these goals. Lane and Reber (2008) suggest the following postmodern themes: trust or social capital, post-materialism, egalitarianism, individualism, or the achievement orientation and gender or feminism.

\section{Definition of Culture}

Recognising that there is no universally accepted definition of culture, and that research indicates that most are either extensively inclusive or exclusion, often based on research or observation, the following definition is proposed.

The notion of culture varies based on numerous and diverse criteria that includes variables such as, age, financial, and educational class, gender, religion, upbringing and experience. The experience of culture is both bestowed by the environment and is learnt through self-adaptation. Culture is equally tacit and explicit. Therefore, culture is inherited and progressively elaborated. In some instances, culture is the way one lives and confronts daily challenges of failures and achievements.

\section{Overview of Czech Culture}

Czech culture is neither a hybrid of the Germanic or the Slavic. It is uniquely Czech. 
Czechs throughout the centuries have developed a unique view of themselves and of the world. The sense of survival creates a mentality that is flexible to adapt to multiple circumstances not necessarily positive. It is far from perfect as it is human. History has moulded the Czech vision to one of innovation and foreign ideologies but not necessarily to the foreigners from whom the ideas originated.

\section{Social Stability and Existence}

Both the Czech nation and culture remain resilient despite the world around it. For most Czechs, life is good and when time permits include a trip to the country cottage. For those more fortunate, these may include a family holiday to Croatia, skiing in Italy, or a winter break in more warmer climes.

There are national issues that occasionally disturb the collective consciousness such as the influx of migrants, and the rise of populism in the region and more recently, globally. There is a general wave of contentment that, nevertheless, does not extend to the political arena. Czechs continue to show disdain with their leaders. Demonstrations at Prague Castle or on Václavské Náměstí remind the average citizen that something is amiss with their politicians. However, given the numerous coalitions, technocrat, and minority governments over the years, this too has become part of life. Despite these issues, life continues and is for many, the highest lifestyle experienced in decades.

With a standard of living and lifestyle, equal or at times, superior to other European Union members, there is concern over the wage imbalance especially for those professions upon which the Czech state is heavily dependent: civil protection, medicine, and education.

Inglehart and Welzel (2010) suggest that Czechs are moving towards self-expression and values that generally comprise a participative attitude, trust and tolerance and a sense of wellbeing. There exists a higher degree of individuality and democratic growth indicative of a knowledge society.

However, possible threats to social stability maybe on the horizon subject to the global socio-political climate, governmental policies and legislation following the 2017 national parliamentary elections and the 2018 presidential elections. Concerns have also been raised on the status of nongovernmental organisations and their relationship to the various governments of the day (Frič, 2005). Increasing Euro-scepticism, possible Russian meddling in local media, and politics (Vejvodová et al., 2017) and lastly, the rise of populist governments in neighbouring countries equally represent growing concerns to the Czech sense of well-being. Any negative impact from either internal or external threats could differ from the relatively stable social conditions Czechs currently enjoy. As Inglehart and Welzel (ibid., 552) state "modernization's changes are not irreversible".

\section{Gender Equality}

On the surface, Czechs are still a maledominated culture although there is growing concern and recognition that further action is required in this area based on the advances made in other European Union member states to represent over half of the population in the legislatures at the local, regional, and national levels. Women have minor access to leadership positions both in the public and private workforce. It is important to note that maternity leave in the nation is generous in comparison with other Western nations with some critics claiming that this is yet another clandestine effort to perpetuate classical family role models.

Familial responsibilities are mostly shared between both partners as they are employed outside the home. The notion of the male breadwinner is progressively on the verge of disappearance. The Czech female is highly resourceful and often holds the position of head of the family either inadvertently or by choice. The feminist movement has yet to reach the Czech nation to the same degree as elsewhere. Czechs still enjoy beauty pageants, 'sexy' adverts appear on television promoting erectile dysfunction medications and 'girly' calendars popular in the United States during the 1950s and 1960s are still available for purchase. To conclude that gender equality is a primordial concern of the nation would be an exaggeration if compared to the standards expressed by the French President or the Canadian Prime 
Minister.

Javorník (2012:12) suggests that the current conditions are largely attributable to the Communist Czech state that promoted gender specific standards for families. The stay-at-home Mum was the norm during pregnancy leave. Writing from an American perspective, RatzerFarley (2013) states gender equality concerns are just not an issue. Feminism was branded as a "bourgeois ideology that offered nothing to the Socialist woman" (ibid., 6). The official state attitude was a far cry from the bra-burning demonstrations of the 1960s and 1970s in the West. There is a stereotypical image in Czech society that equates feminism to 'men haters' and hence, not prioritised in a male-dominated culture. Mysíková (2012:342) based on recent data, confirms that "gender wage difference has been substantially deteriorating in the Czech Republic" with men holding better jobs and positions than their female counterparts.

\section{Goals and Achievements}

Czechs are extremely goal-centred and pride themselves on their achievements. As the English were viewed as a nation of shopkeepers during the nineteenth and twentieth centuries, Czechs are a nation of entrepreneurs. It is not uncommon for a regular full-time employee to own their own business. Even students start early with a part-time position but a full-time personal venture. Work is not an alien concept to the Czech as the transitional experienced in post 1989 "delivered individual, contractual and much freer labour relations within a different context" (Večerník, 2006:1225).

Czechs like other Western cultures do take lower-paying jobs especially as interns to seek advancement. Whether it be purely for financial gain or for professional recognition, Czechs tend to overburden themselves. Prioritisation at times suffers albeit unintentionally given the workload and high self-expectations.

In a recent study, Lanik, Thornton, and Hoskovcová (2009) compare Czechs and Americans based on the Friedman 'flattening hypothesis' using the seventeen facets of the Achievement Motivation Inventory (AMI). Czechs scored higher than the American participants in the following inventory dimensions: compensatory effort, competitive- ness, eagerness to learn, flexibility, self-control, and status orientation (ibid., 81). Overall, these indicators represent a high inner sense of achievement and the willingness to expend effort to avoid falling at a work task. The desire to do better, to enlarge personal knowledge, to accept change, and to attain high-status in both one's personal and professional life (ibid., 74).

Lanik, Thornton, and Hoskovcová reference a comparable study, conducted by Hoskovcová and Niederlová (2007) that comprised Czech and German students. Results demonstrated a higher degree of individualism and facets of ambition including pride in the tasks involved from the Czech participants more than the Germans. Czech students did score lower on dominance and success that the authors suggest that the Czech students "may therefore tend to choose fewer challenging tasks compared with German students” (Lanik et al., 81).

\section{Politics and Elites}

Czechs usually avoid politics for numerous reasons, whether they feel that their elected officials do not represent their own personal values, out of disgust to the numerous corruption scandals or apathy. Given that the national government is a parliamentary system, the selection of political alternatives and parties is varied. Mareš (2012) warns of the various characterisations of the political extreme-right and their innumerable manifestations since the early 1990s. However, since 1989, multiple governments of a minority, coalition, and technocrat alignment, nurture a progressively lessened Czech interest in government. Fortunately, or unfortunately, these are democratic consequences of a reflection of the people's will. Czechs have certainly realised this. Czech elites are difficult to determine, the culture lacks any contemporary heroes or positive role models except for the individuals who excel in sport and the high cultural arts who have gained international recognition. Czechs continue to identify with their past heroes with the most recent exception being that of Václav Havel. All others are dated solidly, but are not obsolete, in the past and include Jan Hus, and Charles IV. In other words, they are selected based on their contribution to the culture and to the positive notion of the 
Czech psyche.

Technically speaking, there are the business elite comprised of the 'millionaires and billionaires' category. Some of them warrant a positive cultural image due to their philanthropy or specific advancements in the Czech arts or sciences. The elitist recognition is awarded not based on their notoriety but positive contributions. As with other Western cultures, the standard elites include elected parliamentarians, the clergy, and the media.

\section{CONCLUSION}

The findings demonstrate that Hofstede's ecological fallacy of attributing his cultural dimensions to individuals is supported. The literature presents an image of a culture still in transition despite EU adhesion. Like many fellow member states, culture is still one of evolution from state sponsored socialism to a post-modern state. The frequent contributions from Czech sociologists cited in this work confirm the more thought-provoking aspects of their culture vis à vis diversity. In this capacity, they substantiate many of the traits previously recognised such as, scepticism but also pragmatism. Readers have been provided with an abbreviated version of the review. The fully documented examination is sufficient to qualify and quantify differences once the project survey has been completed.

\section{ACKNOWLEDGEMENT}

This paper is one of the research outputs of the project IGA VŠE No. IP310048 financially supported by the University of Economics, Prague in conjunction with the Cross-Cultural Management Centre.

\section{REFERENCES}

Ailon, G., (2008). Mirror, mirror on the wall: cultural consequences in a value test of its own design. The Academy of Management Review, vol.33, No. 4

Bilefsky, D., (2016). With Czechia, Czech Republic hopes vowels will solve name puzzle. The New York Times: 14 April 2016. Retrieved 7 January 2018 from https://www.nytimes.com/2016/04/15/worl d/europe/czech-republic-seeking-a- snappier-nameconsiders-a-change.html

Blažejovská, M., (2013). Czech Republic. Published in Hokovský, R., and Kopal, J. Politics and Policies of Integration. Prague: Open Societies Foundation.

Bludau, H., (2009). The good dissident Švejk: an exploration of Czech morality and cultural survival. Kosmas journal. Czechoslovak Society of Arts and Sciences.

Brodský, J. (2000). Little Czechs, Big Europe. Central Europe Review. Vol. 2, No. 20, 22 May 2000.

Brodský, J. (2004). Czech identity on returning to Europe. 2003-2004: 1-2 Sien Quarterly, 9.

Bryant, C., (2005). “Czechness” then and now. Multicultural Centre Prague.

Bryant, C., (2004). Acting Czech, Marking Germans: nationality politics in Bohemia and Moravia, 1939 - 1947. GHI Bulletin No. 34 spring.

Čaněk, M., And Grill, J., (2004). The Past and Present of Czech Multiculturalism - Pavel Barša interviewed by Marek Čaněk and Jan Grill. Social and cultural diversity in Central and Eastern Europe: old factors and new. Seminar proceedings, Prague, October 2004. Multicultural Centre Prague.

Danis, W., Liu, A., And Vacek, J., (2011). Values and upward influence strategies in transition: evidence from the Czech Republic. Journal of Cross-Cultural Psychology. 2011, 42, pp. 288.

Diller, J. (2019). Cultural Diversity. London: Cengage

Dunbar, E., And Simonová, L., (2003). Individual difference and social status predictors of anti-Semitism and racism US and Czech findings with the Prejudice / Tolerance and right-wing authoritarianism scales. International Journal of Intercultural Relations

Englund, T., (2004). The Czechs in a Nutshell. Prague: Baset.

European Commission, (2018). Digital Transformation Scoreboard 2018. European Union businesses go digital: opportunities, outcomes and uptake. Luxembourg: Publications Office of the European Union, 2018. 
Frič, P., (2005). The third sector in the policy process in the Czech Republic. The London School of economics and political science. Centre for Civil Society. Number 6 third sector European policy working papers.

Hanley, S., (2002). The political context of EU accession in the Czech Republic. The Royal Institute of international affairs. October 2002.

Hamplová, D., And Nešpor, Z., (2009). Invisible religion in a 'non-believing' country: the case of the Czech Republic. Social Compass. $56(4), p p .581-597$.

Havrylyshn, O., (2007). 15 years of transformation in the post-communist world. Centre for Global liberty and prosperity. The CATO Institute. Number 4.

Hays, P. (2008). Addressing cultural complexities in practice: Assessment, diagnosis, and therapy. Washington: American Psychological Association

Hays, P. (2012). Connecting across cultures: The helper's toolkit. Thousand Oaks: SAGE

Hofstede, G., (2001). Culture's Consequences. 2nd ed. London: Sage Publications.

Hokovský, R., \& Janda, J. (2013). Czech Republic. Published in Hokovský, R., and Kopal, J. Politics and Policies of Integration. Prague: Open Societies Foundation.

Holý, L., (1996). The little Czech and the great Czech Nation: national identity and the post-communist social transformation. Cambridge studies and social and cultural anthropology. Cambridge: Cambridge University Press.

Illner, M., (1994). The international context of Czech transformation. Czech Sociological Review, volume 2, number 1

Inglehart, R., And Welzel, C., (2005). Modernization, cultural change, and democracy: the human development sequence. Cambridge University Press.

Inglehart, R., And Welzel, C., (2010). Changing Mass priorities: the link between modernization and democracy. Reflections. Vol. 2, No 2.

Javorník, J., (2012). State socialism: dismantling the male Breadwinner family model in Central and Eastern Europe. Welfare Studies.
Department of Sociology working paper 14 / 2012.

Kopeček, M., (2002). Politics, anti-politics, and Czechs in Central Europe: The idea of "Visegrád Cooperation and Its Reflection in Czech politics in the 1990s. Published in In Questionable Returns. Ed. A. Bove, Vienna: IWM Junior Visiting Fellows Conferences, Vol. 12.

Lane, J-E., \& Reber, F. (2008). The Post-Modern Society: Which are the Basic Value Orientations? Contemporary Issues, Vol, 1 , No. 1.

Lanik, M., Thornton, G., And Hoskovcová, S., (2009). A flat world? A comparative study of achievement motivation in the Czech Republic and the United States. Studia Psychologica, 51, 2009

Lenski, G., (1970). Human Societies. Toronto McGraw-Hill Book Company

Leung, K., Bhagat, R., Buchan, N., Erez, M., \& Gibson,C. (2005). Culture and International Business: recent advances and their implications for future research. Journal of International Business Studies (2005) 36

Lord, C., (2004). Why Czech racism is different from Western racism. Retrieved 20 December 2018 from http://www.think.cz/issue/34/3.html

Luthans, F., And Doh, J., (2012). International Management culture, strategy, and behavior: New York: McGraw-Hill Irwin.

Mansfeldová, Z., (2003). Democracy in the Czech Republic and assessment of attitudes towards democracy and democratic values of the Czech population 1990 - 2001. Working Papers of the Research Centre for East European Studies. Arbeitspapiere und Materialien - Forschungsstelle Osteuropa, Bremen

Mareš, M.,(2012). Right-wing extremism in the Czech Republic. International policy analysis, September 2012.

Mysíková, M., (2012). Gender wage Gap in the Czech Republic and central European countries. Prague economic papers, 3

Nedomová, A., And Kostelecký, T., (1997). The Czech National Identity. Czech Sociological Review. Vol. 5 No 1 
Nollen, T., (1997). Culture Shock! Czech Republic. Portland: Graphic Arts Center Publishing Company.

Otfinoski, S., (1997). The Czech Republic. New York: Facts on File.

Pehe, J., (1996). Are we our Own Worst Enemy? Czech provincialism. Published in The New Presence, October 1996. Retrieved 7 January 2018 from

http://www.pritomnost.cz/archiv/en/1996/1 996_10.pdf

Pehe, J., (1995). The choice between Europe and provincialism. Transition. Retrieved 7 January 2018 from www.pehe.cz/clanky/1995/199514July1995-Transition.pdf

Piurko, Y., Schwartz, S., And Davidov, E., (2011). Basic personal values and the meaning of left - right political orientations in 20 countries. Political psychology. Epub ahead of print. Posted at the Zurich Open Repository and Archive, University of Zurich.

Pridham, G., (2009). Democratic consolidation in the Czech Republic: comparative perspectives after 20 years of political change. Paper for conference on 20 years of Czech Democracy, organized by The Institute for comparative political research, Masaryk University, Brno, 14th September 2009.

Rabušic, L., (2001). Value change a demographic behaviour in the Czech Republic. Czech Sociological Review, Vol. 9

Ralston, D., Giacalone, R., \& Terpstra, R. (1994). Ethical perceptions of organisational politics. Journal of Business Ethics, 13.

Ratzer-Farley, K., (2013). Feminism movement in Czech Republic. Modern media and democracy, Prague Freedom Foundation, Kent State University.

Richard, M., (2014). Roma and Czechs: mindful a difference. Southern Anthropologist 36 (2).

Schwartz, S. H., (1992). Universals in the content and structure of values: Theory and empirical tests in 20 countries. Advances in experimental social psychology, Vol. 25

Shleifer, A., And Treisman, D., (2014). Normal countries: the east 25 years after communism. Foreign Affairs, 93 (6)

Smith, M., And Matějů, P., (2012). Two decades of value change: the crystallization of meritocratic and egalitarian beliefs in the Czech Republic. Social Justice Research. 25

Taras, V., Kirkman, B., And Steel, P., (2011). Improving National Cultural indices using a longitudinal meta-analysis of Hofstede's Dimensions. Journal of World Business. 47

Urban, O., (1995). One Hundred Years of the Czech Question. Czech Sociological Review, volume 3, number 121

Urban, J., (1996). A slave in search of a master. Published in The New Presence. October 1996.Retrieved 7 January 2018 from http://www.pritomnost.cz/archiv/en/1996/1 996_10.pdf

Vachudová, M., (2001). The Czech Republic: the unexpected force of institutional constraints. Published in: Zielonka, J., and Pravda, A., Democratic consolidation in Eastern Europe, Volume 2: International and transnational factors. Oxford: Oxford University Press

Večerník, J., (2006). Work Values and Job Attitudes in the Czech Republic between 1997 and 2005. Czech Sociological Review, Vol. 42, No 6

Vejvodová, P., Janda, J., And Vichová, V. (2017), The Russian connections of far-right and paramilitary organizations in the Czech Republic. Political Capital Institute

Vrabcová, D., Vacek, P., And Lašek, J., (2008). Country report: the Czech Republic. Educational policies that address social inequality, December 2008

\section{ABOUT THE AUTHORS}

Richard Brunet-Thornton, email: richard.brunetthornton@vse.cz

Dr. Richard Brunet-Thornton, FRSA, MIM, MBA is a member of the Department of Management, Faculty of Business Administration of the University of Economics, Prague. Managing Director of the Cross-Cultural Management Centre and Executive Consultant of the Centre for Digital Transformation. Research interests are centred on intercultural management 
and communications, intercultural negotiation styles, cultural anthropology and ethnology, and cross-cultural knowledge management. Given his 45-year experience in the IS/IT industry, Richard's interest includes international project management and the cultural aspects of digital transformation. He holds editorial positions on various scholarly journals and publications. Richard is a Fellow of the Royal Society of the Arts (UK) and a member of the American Psychological Association.

Dr. Tobias Cramer a native of Leipzig, Germany completed his studies of business and education at the University of Technology Dresden. Already during his studies, he gained broad practical experience in crosscultural cooperation. Fascinated by crosscultural similarities and differences, he addressed himself to cross-cultural cooperation in multinational teams during his doctoral study at the University of Economics, Prague. He currently works as a lecturer and trainer in cross-cultural as well as diversity management. His recent visiting lectures included the University of Northern Colorado (US). and the Shandong University of Finance and Economics (China) Tobias is an Executive Consultant at the Centre for Cross-Cultural Management.

Dr. Petr Jirsák is a member of the Department of Logistics, Faculty of Business Administration of the University of Economics, Prague. Managing Director of the Centre for Digital Transformation. Research interests include supply chain processes such as, demand planning, supply planning and management, warehousing and logistic services, logistic providers, global supply chain strategies, employment of lean management in supply chain processes, implementation road maps and automation and digitisation strategies, municipal logistics in the era of Smart Cities and last but not least, the impact of additive manufacturing on supply chain performances. Petr conducts research for the Technological Agency of the Czech Republic and the Ministry of Transportation. Recent involvement comprised municipal logistics and waste collection using the IoT.
Equally, Petr provides consulting services for private enterprise in the areas of distribution strategies and warehousing. Petr regularly presents his findings and recommendations at both academic and professional conferences. 